\title{
Influence of metal ions and organic carbons on denitrification activity of the halotolerant bacterium, Paracoccus pantotrophus P16 a strain from shrimp pond
}

\author{
Punyawatt Pintathong \\ Biotechnology Program \\ School of Agricultural Technology \\ Walailak University \\ Thasala, Nakhon Si Thammarat 80160 \\ Thailand \\ David J. Richardson \\ Faculty of Science \\ School of Biological Sciences \\ University of East Anglia \\ Norwich, NR4 7TJ \\ United Kingdom \\ Stephen Spiro \\ Department of Molecular and Cell Biology \\ University of Texas at Dallas \\ 800 W Campbell Road, Richardson \\ Texas 75083-0688, USA \\ Wanna Choorit* \\ Biotechnology Program \\ School of Agricultural Technology \\ Walailak University \\ Thasala, Nakhon Si Thammarat 80160 \\ Thailand \\ Tel: 6675672355 \\ Fax: 6675672302 \\ E-mail: cwanna@wu.ac.th
}

Financial support: This work was supported by The Royal Golden Jubilee (RGJ) Ph.D. Program (2.B.WL/45/A.1).

Keywords: metal ions, nitrate reductase, nitrite accumulation, nitrite reductase, Paracoccus pantotrophus.

Abbreviations: C/N: carbon per nitrate

DCW: dry cell weight

$\mathrm{Fe}^{3+}$ : ferric ion

$\mathrm{Mo}^{6+}$ : molybdenum ion

$\mathrm{OD}_{660}$ : optical density at $660 \mathrm{~nm}$

The effect of metal ions, ferric ion $\left(\mathrm{Fe}^{3+}\right)$ and molybdenum ion $\left(\mathrm{Mo}^{6+}\right)$ on the denitrification process of Paracoccus pantotrophus P16 grown under saline conditions was investigated. Results revealed that the dosages of added $\mathrm{Fe}^{3+}$ and $\mathrm{Mo}^{6+}$ significantly accelerated nitrate utilization and nitrite accumulation. Enzymatic studies revealed that the membrane-bound nitrate reductase and the periplasmic nitrite reductase had activities of $998 \pm 28$ and $373 \pm 18 \mathrm{nmol}^{(\mathrm{mg} \text { protein })^{-1}}$ min $^{-1}$, respectively after growing Paracoccus pantotrophus P16 in medium supplemented with $1.5 \mu \mathrm{M}$ $\mathrm{Fe}^{3+}$. If provided with $1.5 \mu \mathrm{M} \mathrm{Fe}{ }^{3+}$ and $2.4 \mu \mathrm{M} \mathrm{Mo}^{6+}$, the membrane-bound nitrate reductase activity increased to
$6,223 \pm 502 \mathrm{nmol}\left(\mathrm{mg}\right.$ protein) ${ }^{-1} \mathrm{~min}^{-1}$ and the periplasmic nitrite reductase was $344 \pm 20 \mathrm{nmol}(\mathrm{mg}$ protein) ${ }^{-1} \min ^{-1}$. The results indicated that an addition of $\mathrm{Fe}^{3+}$ and $\mathrm{Mo}^{6+}$ led to an overstimulation of nitrate reductase activity as compared with nitrite reductase activity. When glucose was supplied, the minimal ratio of carbon per nitrate $(\mathrm{C} / \mathrm{N})$ was $2.31 \mathrm{mg} \mathrm{C} / \mathrm{mg} \mathrm{NO}_{3}{ }^{-} \mathrm{N}$ with denitrification yield of $0.45 \mathrm{~g} \mathrm{NO}_{3}{ }^{-}-\mathrm{N} / \mathrm{g} \mathrm{C}$. Addition of ethanol instead of glucose, the minimal ratio of $\mathrm{C} / \mathrm{N}$ was $1.15 \mathrm{mg} \mathrm{C} / \mathrm{mg} \mathrm{NO}_{3}{ }^{-} \mathrm{-N}$ with denitrification yield of $1.08 \mathrm{~g} \mathrm{NO}_{3}^{-}-\mathrm{N} / \mathrm{g} \mathrm{C}$.

Waste nitrogen containing compounds, of both organic

*Corresponding author 

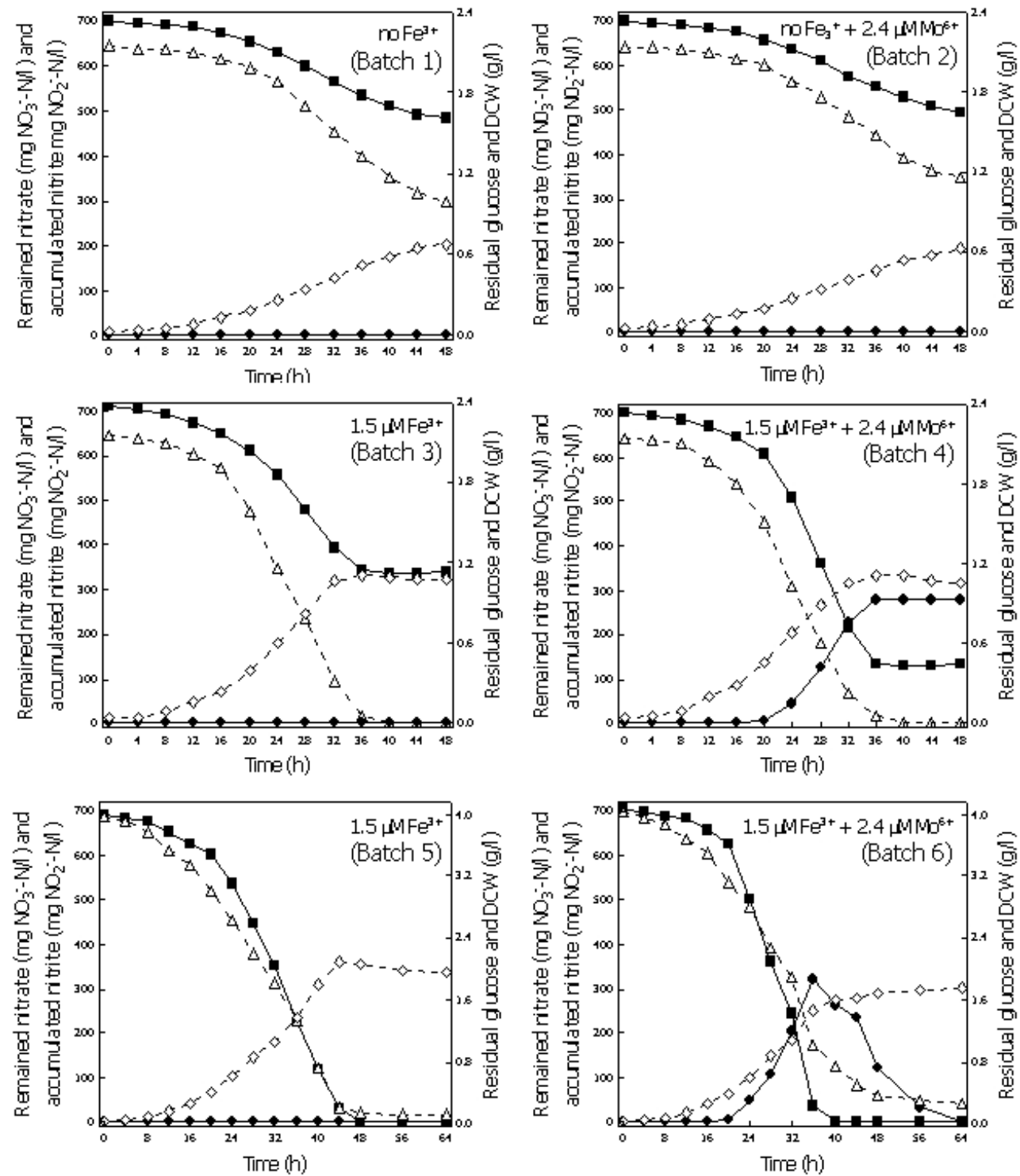

Figure 1. Growth $(\diamond)$, concentrations of glucose $(\Delta)$, nitrate $(\square)$ and nitrite $(\bullet)$ in batch denitrification tests of Paracoccus pantotrophus P16 grown in a synthetic medium containing $700 \mathrm{mg} \mathrm{NO}_{3}^{-}-\mathrm{N} / \mathrm{l}$ and $800 \mathrm{mg}$ C/l glucose (batches 1-4) or 1,600 mg C/l glucose (batches 5-6). Standard deviations of growth, glucose concentrations did not exceed $5 \%$ while for nitrate and nitrite concentrations did not exceed $10 \%$ of their corresponding values.

nitrogen (protein and amino acids) and inorganic nitrogen (ammonia, nitrate and nitrite), can be transformed to nitrogen gas by the action of microorganisms (van Rijn et al. 2006). The first step is ammonification in which all the organic- $\mathrm{N}$ is converted to ammonia. This is then oxidized by nitrifying bacteria to nitrate and then converted to nitrogen gas by denitrification (Crab et al. 2007). Inorganic nitrogen, in the form of ammonia, nitrate and nitrite have been considered as compounds that can be toxic to aquatic animals (Cheng and Chen, 2001; Jensen, 2003; Kir et al. 2004; Yildiz and Benli, 2004), and create environmental problems, such as eutrophication of rivers. Some attempts to overcome these problems have been conducted using good agricultural practices (Mishra et al. 2008), and in many areas local authorities have enforceable environmental regulations on the maximum concentrations of nitrogen compounds permitted in effluent discharges (van Rijn et al. 2006). This has lead to an increased emphasis on treating wastewater with high nitrogen levels, for example by means of biological methods. Paracoccus spp. are capable of reducing nitrate to nitrogen gas (Rezić et al. 2006) and are widely found in nitrogen rich environments. As reported by Foglar et al. (2005) Paracoccus was the dominant bacterial species found after wastewater from an industrial yeast process was biologically treated. Paracoccus halodenitrificans was isolated from sediments and used to reduce levels of perchlorate and nitrate (Okeke et al. 2002). 
It is known that many parameters, such as oxygen level, temperature, $\mathrm{pH}$, nitrate concentration, carbon per nitrate $(\mathrm{C} / \mathrm{N})$ ratio, $\mathrm{NaCl}$ concentration and trace elements influence denitrification (Cervantes et al. 1998; Glass and Silverstein, 1998; Bilanovic et al. 1999; Glass and Silverstein, 1999; Carrera et al. 2003; Estuardo et al. 2008). Denitrification involves several proteins that require metal ions as a cofactor (Ferguson, 1998; Philippot and Højberg, 1999). $\mathrm{Mo}^{6+}$ acts as a component of the molybdenum cofactor of nitrate reductase, while $\mathrm{Fe}^{3+}$ is required for the cytochrome subunits of both nitrate and nitrite reductases. A high dosage of trace metals (Fe, $\mathrm{Cu}, \mathrm{Zn}, \mathrm{Mo}$ and $\mathrm{Mn}$ ) caused an increase in denitrification rate from 200 to $700 \mathrm{~g}$ $\mathrm{NO}_{\mathrm{x}}-\mathrm{N} / \mathrm{d}$. However, only $\mathrm{Fe}$ was proved to be a significant influence on rates of denitrification, and the combination of $\mathrm{Fe}+\mathrm{Mn}$ had greater effect (Labbé et al. 2003). Cyplik et al. (2007) reported that an addition of $\mathrm{Fe}, \mathrm{Cu}$ and $\mathrm{Mo}$ significantly increased the specific nitrate reduction rate of Haloferax denitrificans. The nature of the carbon substrate also influences denitrification rates. For example an accumulation of nitrite was $5 \mathrm{mg} \mathrm{NO}_{2}{ }^{-} / \mathrm{l}$ when sucrose was used as a carbon source (Gómez et al. 2000), but ethanol and methanol supported a higher denitrification rate as compared to sucrose (Lorrain et al. 2004). Thus, in order to complete denitrification ( $\mathrm{N}_{2}$ gas formation) the factors influencing the denitrification process must be investigated. In this study, we isolated a salt tolerant bacterium Paracoccus pantotrophus P16 from a mud sample obtained from a shrimp pond at Nakhon Si Thammarat, in the southern part of Thailand. Glucose and ethanol were selected as carbon sources supporting denitrification in this bacterium. Glucose is normally used as the carbohydrate source for shrimp feeds, and also for controlling water quality (Shiau, 1998; Avnimelech, 1999; Hari et al. 2004; van Rijn et al. 2006; Asaduzzaman et al. 2008). On the other hand, ethanol is superior in terms of high denitrification rates with low biomass production (Gómez et al. 2000; Lorrain et al. 2004). The aims of this study were to determine the influence of added metal ions and carbon sources on the denitrification process catalysed by Paracoccus pantotrophus P16.

\section{MATERIALS AND METHODS}

\section{Bacteria, media and starter culture preparation}

The bacterial strain P16 was isolated from a mud sample obtained from a shrimp pond in Nakhon Si Thammarat, Thailand. It was identified as a member of Paracoccus and closely related to Paracoccus pantotrophus based on its morphological, biochemical and physiological properties, and 16S rDNA sequencing. Under denitrifying conditions, it can grow in medium containing $\mathrm{NaCl}$ up to $6 \%$. Growth was observed at $25-47^{\circ} \mathrm{C}$. Sugar substrates, i.e. glucose, fructose, sucrose and maltose were excellent carbon sourcesfor growth, while growth in the presence of methanol was not observed. The bacterium can tolerate and
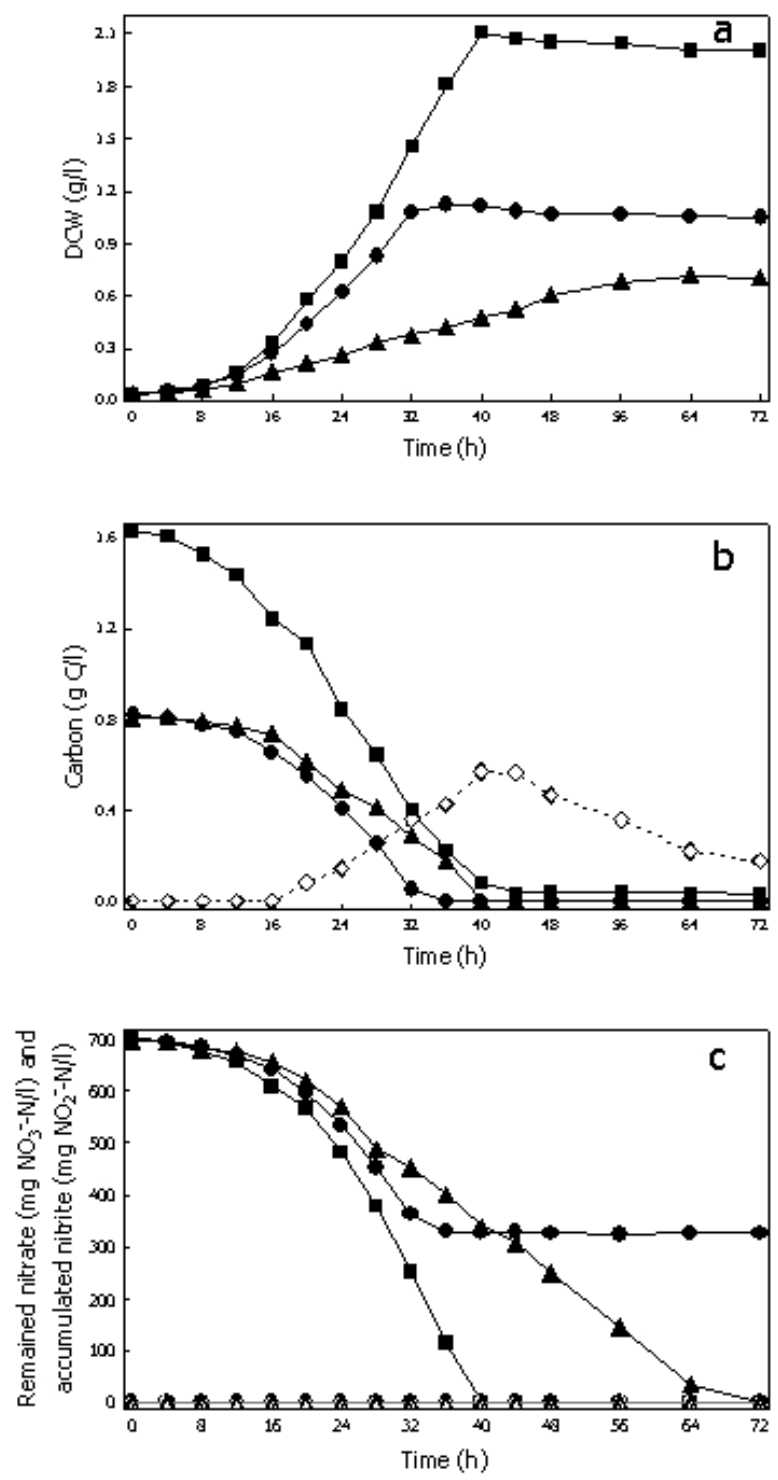

Figure 2. Growth (a), carbon (b), nitrate and nitrite concentrations (c) in batch denitrification tests of Paracoccus pantotrophus P16 grown in a synthetic medium containing $4.5 \mu \mathrm{M} \mathrm{Fe}{ }^{3+}, 700 \mathrm{mg} \mathrm{NO}_{3}^{-}-\mathrm{N} / \mathrm{l}$ and various concentrations of carbons. $\boldsymbol{\Delta}=800 \mathrm{mg} \mathrm{C} / \mathrm{l}$ ethanol, $\bullet=800 \mathrm{mg} \mathrm{C} / /$ glucose and $\boldsymbol{\|}=1600 \mathrm{mg} \mathrm{C} / \mathrm{l}$ glucose . Acetate $(\diamond)$ was detected when ethanol was utilized. Levels of nitrite were represented as $\Delta$. Standard deviations of growth, glucose concentrations did not exceed $5 \%$ while for nitrate and nitrite concentrations did not exceed $10 \%$ of their corresponding values.

reduce nitrate and nitrite at about 2,100 $\mathrm{mg} \mathrm{NO}_{3}{ }^{-} \mathrm{-N} / \mathrm{l}$ and $400 \mathrm{mg} \mathrm{NO}{ }^{-}-\mathrm{N} / \mathrm{l}$ to $\mathrm{N}_{2}$ gas, respectively. Moreover, it can carry out aerobic denitrification (unpublished data).

The synthetic medium used was modified from Sasaki et al. (1988) and contained, g/l, $0.5 \mathrm{KH}_{2} \mathrm{PO}_{4}, 0.5 \mathrm{~K}_{2} \mathrm{HPO}_{4}, 0.8$ $\left(\mathrm{NH}_{4}\right)_{2} \mathrm{HPO}_{4}, 0.2 \mathrm{MgSO}_{4} \cdot 7 \mathrm{H}_{2} \mathrm{O}, 0.053 \mathrm{CaCl}_{2} \cdot 2 \mathrm{H}_{2} \mathrm{O}, 0.001$ $\mathrm{MnSO}_{4} \cdot 5 \mathrm{H}_{2} \mathrm{O}, 0.01$ yeast extract, $30 \mathrm{NaCl}$ and $\mathrm{x}$ glucose or ethanol with the $\mathrm{pH}$ of the medium adjusted to 7.5. For denitrifying growth, $\mathrm{FeCl}_{3} \cdot 6 \mathrm{H}_{2} \mathrm{O}$ and $\mathrm{Na}_{2} \mathrm{MoO}_{4} \cdot 2 \mathrm{H}_{2} \mathrm{O}$ were 
Table 1. Effect of added $\mathrm{Fe}^{3+}$ and $\mathrm{Mo}^{6+}$ on activities of nitrate and nitrite reductase assayed in subcellular fractions and whole cells of Paracoccus pantotrophus P16.

\begin{tabular}{|c|c|c|c|c|c|c|}
\hline \multirow{2}{*}{ Batch $^{\text {b }}$} & \multicolumn{2}{|c|}{ Trace metal $(\mu \mathrm{M})$} & \multicolumn{2}{|c|}{$\begin{array}{c}\text { Specific activity } \\
{\left[\mathrm{nmol}(\mathrm{mg} \text { protein })^{-1} \mathrm{~min}^{-1}\right]^{\mathrm{a}}}\end{array}$} & \multicolumn{2}{|c|}{$\begin{array}{c}\text { Specific activity } \\
{\left[\mathrm{nmol}(\mathrm{mg} \mathrm{DCW})^{-1} \mathrm{~min}^{-1}\right]^{\mathrm{a}}}\end{array}$} \\
\hline & $\mathrm{Fe}^{3+}$ & $\mathrm{Mo}^{6+}$ & $\begin{array}{l}\text { Membrane-bound } \\
\text { nitrate reductase }\end{array}$ & $\begin{array}{l}\text { Periplasmic nitrite } \\
\text { reductase }\end{array}$ & $\begin{array}{l}\text { Nitrate } \\
\text { reductase }\end{array}$ & $\begin{array}{l}\text { Nitrite } \\
\text { reductase }\end{array}$ \\
\hline 1 & - & - & $387 \pm 60$ & $223 \pm 13$ & $39 \pm 4$ & $20 \pm 1$ \\
\hline 2 & - & 2.4 & $536 \pm 6$ & $187 \pm 24$ & $44 \pm 4$ & $18 \pm 3$ \\
\hline 3 & 1.5 & - & $998 \pm 28$ & $373 \pm 18$ & $240 \pm 30$ & $162 \pm 13$ \\
\hline 4 & 1.5 & 2.4 & $6,223 \pm 502$ & $344 \pm 20$ & $324 \pm 21$ & $148 \pm 22$ \\
\hline
\end{tabular}

${ }^{a}$ Values represent mean \pm S.D. of three replicates.

${ }^{b}$ Batches 1-4 were performed in the medium containing glucose as a carbon source and at the ratio of $\mathrm{C} / \mathrm{N}=1.15$.

also supplemented as sources of $\mathrm{Fe}^{3+}$ and $\mathrm{Mo}^{6+}$, respectively. Glucose (2 g/l) was used as a carbon source for starter culture preparation.

The starter cultures were prepared by cultivating Paracoccus pantotrophus P16 in $500 \mathrm{ml}$ Erlenmeyer flasks containing $200 \mathrm{ml}$ synthetic medium, and incubated in an orbital shaker at $150 \mathrm{rpm}$ at $35^{\circ} \mathrm{C}$ until growth reached late log phase. Cells were then harvested by centrifugation at $12,000 \mathrm{rpm}$ for $15 \mathrm{~min}$. To prepare the inoculum, the cell pellets were washed twice and readjusted to a cell concentration (optical density at $660\left(\mathrm{OD}_{660}\right)$ ) of 1.0 with fresh medium. A $5 \%(100 \mathrm{ml})$ of starter culture was inoculated into the medium.

\section{Effect of $\mathrm{Fe}^{3+}, \mathrm{Mo}^{6+}$ and carbon sources on the denitrification process}

Preliminary studies showed that among metal ions to be tested, $\mathrm{Fe}^{3+}, \mathrm{Mn}^{2+}, \mathrm{Cu}^{2+}, \mathrm{Zn}^{2+}$, and $\mathrm{Mo}^{6+}$, only $\mathrm{Fe}^{3+}$ and $\mathrm{Mo}^{6+}$ affected on growth and denitrification rates of the bacterium P16; $\mathrm{Mn}^{2+}$ enhanced growth when added with $\mathrm{Fe}^{3+}$, and nitrate removal increased corresponding to growth. These data agreed well with the previous results (Labbé et al. 2003; Zhou et al. 2007). Taking these results and those reported by Labbé et al. (2003) and Zhou et al. (2007) together led us to focus attention on the effect of $\mathrm{Fe}^{3+}$ and $\mathrm{Mo}^{6+}$ on denitrification. To investigate the influence of $\mathrm{Fe}^{3+}$ and $\mathrm{Mo}^{6+}$ on the denitrification process, each concentration of metal ion was added into the synthetic medium supplemented with $5 \mathrm{~g} / \mathrm{KNO}_{3}(700 \mathrm{mg}$ $\left.\mathrm{NO}_{3}{ }^{-} \mathrm{N} / \mathrm{l}\right)$ and $2 \mathrm{~g} / \mathrm{l}$ glucose $(800 \mathrm{mg} \mathrm{C} / \mathrm{l}$ ) (Figure 1). This $\mathrm{C} / \mathrm{N}$ ratio was 1.15 . All batch cultures were grown in reactors with a $12 \mathrm{~cm}$ internal diameter and a height of 27 $\mathrm{cm}$. The reactors were maintained at $35 \pm 1^{\circ} \mathrm{C}$ using hot water circulation. Samples were withdrawn from sampling holes (5 $\mathrm{mm}$ in diameter) located $8 \mathrm{~cm}$ from the bottom. The reactors were incubated under static conditions and were gently mixed to produce a homogenous mixture before sampling. Each batch culture was made anaerobic by flushing it with $\mathrm{N}_{2}$ gas prior to inoculation of the bacterial cells and after each sampling. At predetermined time intervals, samples were taken and used to investigate growth, carbon consumption, nitrate and nitrite concentrations. The experiments were done in triplicate.

In order to study the minimal levels of glucose and ethanol required by Paracoccus pantotrophus $\mathrm{P} 16$ to convert nitrate at a concentration of $700 \mathrm{mg} \mathrm{NO}_{3}{ }^{-} \mathrm{N} / \mathrm{l}$ to $\mathrm{N}_{2}$ gas, the carbon per nitrate ratios $\left(\mathrm{C} / \mathrm{N}\right.$ ratio, $\left.\mathrm{mg} \mathrm{C} / \mathrm{mg} \mathrm{NO}_{3}^{-}-\mathrm{N}\right)$ at $1.15,1.73$ and 2.31 were examined. The starter culture was inoculated into the synthetic medium containing predetermined $\mathrm{C} / \mathrm{N}$ ratios as desired. At the specified concentrations metal ions were added (Figure 1). The reactors were operated as previously described.

\section{Subcellular localization and enzyme activity assays}

In order to study enzymatic activities of subcellular fractions and in whole cells, the bacteria were cultivated in reactors under the above described conditions for $24 \mathrm{hrs}$. The synthetic medium was supplemented with $5 \mathrm{~g} / \mathrm{KNO}_{3}$ and $2 \mathrm{~g} / \mathrm{l}$ glucose and different concentrations of metal ions (Table 1). The cells were harvested by centrifugation at $12,000 \mathrm{rpm}$ at $4^{\circ} \mathrm{C}$ and washed twice with $10 \mathrm{mM}$ phosphate buffer, $\mathrm{pH}$ 7.5. Subcellular fractions were obtained by preparing type II spheroplasts as described by Bell et al. (1990). Nitrate and nitrite reductase activities were measured in whole cells and subcellular fractions by following the substrate-dependent oxidation of dithionitereduced benzyl viologen $\left(\mathrm{BV}^{+}\right)$(Bell et al. 1990). 

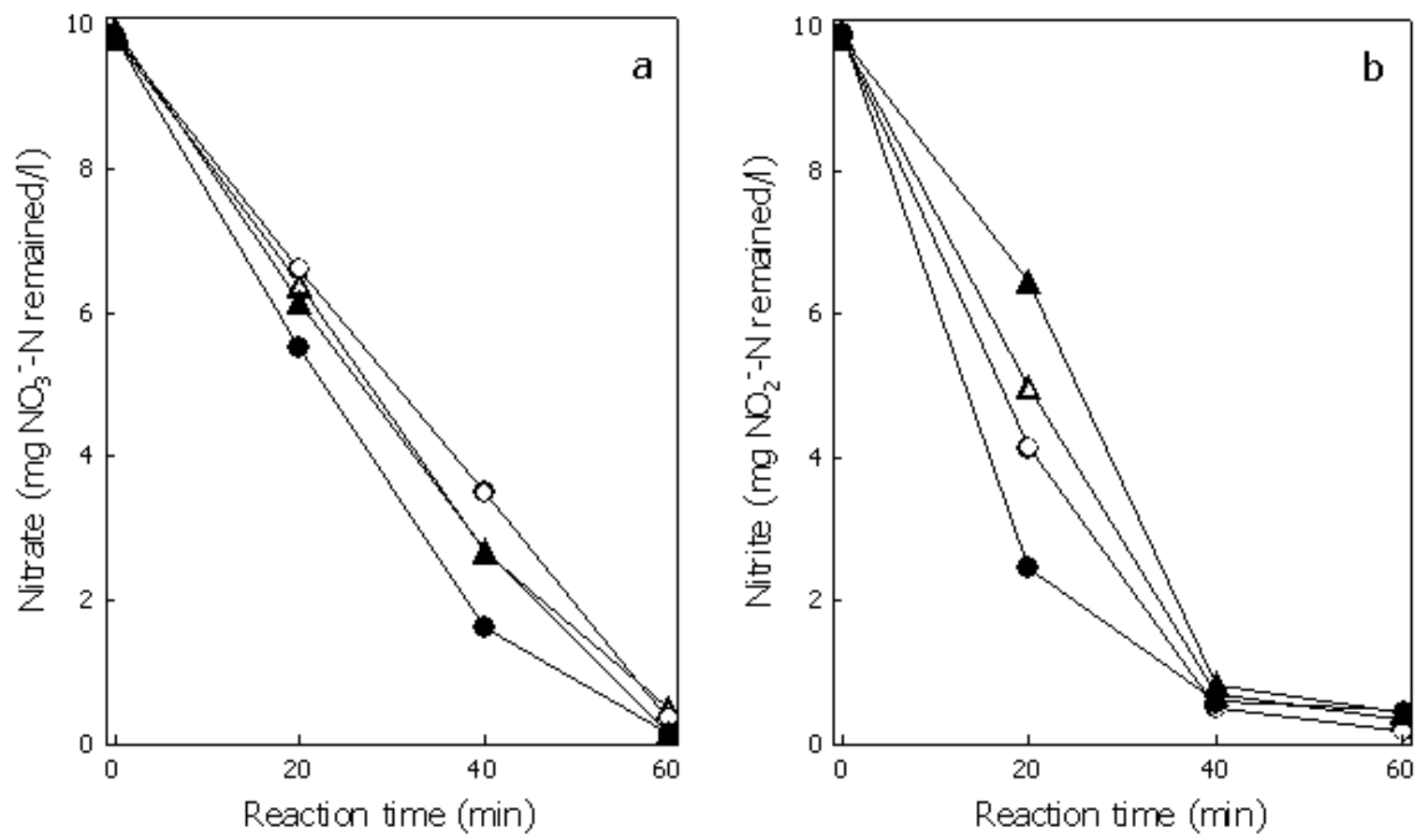

Figure 3. Enzymatic reduction of nitrate (a) and nitrite (b) by intact cells of Paracoccus pantotrophus P16 after growing with glucose at cultivation times of $24 \mathrm{hrs}(\Delta)$ and $32 \mathrm{hrs}(\circ)$ or with ethanol at cultivation times of $24 \mathrm{hrs}(\Delta)$ and $32 \mathrm{hrs}(\bullet)$. Standard deviations of all measurements did not exceed $5 \%$ of corresponding value.

\section{Nitrate and nitrite reduction by intact cells}

Nitrate and nitrite reductase activities of bacterial cells grown in the presence of nitrate (700 $\left.\mathrm{mg} \mathrm{NO}_{3}{ }^{-} \mathrm{N} / \mathrm{l}\right)$ and two carbon substrates, glucose and ethanol, (800 $\mathrm{mg} \mathrm{C} / \mathrm{l})$ were measured as described by Kariminiaae-Hamedaani et al. (2004). During the growth, the cells were collected at predetermined time intervals, by centrifugation and then washed 3 times with $0.1 \mathrm{M}$ potassium phosphate buffer, $\mathrm{pH}$ 7.2. The concentration of cell suspensions were adjusted to $1.0\left(\mathrm{OD}_{660}\right)$ with $0.1 \mathrm{M}$ potassium phosphate buffer. Subsequently, $5 \mathrm{ml}$ of cell suspensions were transferred into reaction tubes and $0.1 \mathrm{ml}$ of concentrated solution of nitrate or nitrite was added into each tube to provide a final concentration of $10 \mathrm{mg} \mathrm{NO}{ }_{3}^{-}-\mathrm{N} / \mathrm{l}$ or $10 \mathrm{mg} \mathrm{NO}_{2}^{-}-\mathrm{N} / \mathrm{l}$, respectively. The reaction was carried out at $35^{\circ} \mathrm{C}$. In the clear supernatant, the remaining concentration of nitrate and nitrite was measured. The enzymatic reduction of nitrate and nitrite was defined in terms of milligrams of nitrate and nitrite remained per liter, respectively.

\section{Analytical methods}

Bacterial growth was measured as turbidity by use of a spectrophotometer (Schimadzu, UV-1601, Kyoto, Japan) at a wavelength of $660 \mathrm{~nm}$ and correlated with the dry cell weight (DCW) measured by drying the cells at $105^{\circ} \mathrm{C}$ to constant weight for 12 hrs. Protein concentrations were determined using the bicinchonic acid assay with bovine serum albumin as the standard. Nitrate and nitrite were analyzed using FIAstar ${ }^{\mathrm{TM}}$ 5000, version 1.3 (FOSS Analytical AB, Höganäs, Sweden) by automated cadmium reduction and the sulfanilamide colorimetric methods, respectively. Glucose, acetate and ethanol were determined by HPLC with Metacarb H Plus (Varian) and a refractive index detector (Waters). Membrane proteins (10 $\mu \mathrm{g}$ total protein) separated by sodium dodecyl sulphate polyacrylamide gel electrophoresis (SDS-PAGE) were blotted onto PVDF membrane (Amersham Biosciences). The blots were probed with a polyclonal primary antibody to Paracoccus NarG that was raised in sheep against purified NarGH protein. Antibody bound to the $\sim 140 \mathrm{kDa}$ NarG was detected using an anti-sheep alkaline phosphatase-conjugated secondary antibody. Antibodies were used at a concentration of $\sim 1 \mu \mathrm{g} / \mathrm{ml}$.

\section{RESULTS}

\section{Effect of $\mathrm{Fe}^{3+}, \mathrm{Mo}^{6+}$ and carbon sources on the denitrification process}

The time profiles of nitrate removal and nitrite accumulation during anaerobic growth of Paracoccus pantotrophus P16 are shown in Figure 1. In the absence of $\mathrm{Fe}^{3+}$ nitrate removal was low, such that the remaining nitrate, from the $700 \mathrm{mg} \mathrm{NO}{ }^{-}-\mathrm{N} / \mathrm{l}$ added, in batches 1 (no $\left.\mathrm{Fe}^{3+}\right)$ and $2\left(\right.$ no $\left.\mathrm{Fe}^{3+}+2.4 \mu \mathrm{M} \mathrm{Mo}{ }^{6+}\right)$ was 483.5 and 493.7 mg $\mathrm{NO}_{3}{ }^{-}-\mathrm{N} / \mathrm{l}$, respectively. The comparison with batch 3 $\left(1.5 \mu \mathrm{M} \mathrm{Fe}^{3+}\right)$ showed that in the presence of $\mathrm{Fe}^{3+}$ the remaining nitrate concentration was much lower at 337.4 
mg $\mathrm{NO}_{3}{ }^{-}-\mathrm{N} / \mathrm{l}$. Furthermore, an addition of $\mathrm{Fe}^{3+}$ together with $\mathrm{Mo}^{6+}$ (batch 4) resulted in a rapid decrease in nitrate concentration and the remaining nitrate was only $132.1 \mathrm{mg}$ $\mathrm{NO}_{3}{ }^{-} \mathrm{-N} / \mathrm{l}$ and under this condition nitrite accumulated to $277.7 \mathrm{mg} \mathrm{NO}{ }_{2}^{-}-\mathrm{N} / \mathrm{l}$. Figure 1 (batch 4) also demonstrates that after 36 hrs to the end of cultivation, the nitrate and nitrite concentrations remained at a constant level. At this point all the glucose substrate had been removed. However, the accumulation of nitrite might indicate that nitrate is a more favoured electron acceptor for this bacterium under this condition as compared with nitrite.

A comparison of the calculated specific growth rates $(\mu)$ of batches $1-4$ showed that increasing $\mathrm{Fe}^{3+}$, resulted in increased $\mu$, from $0.07 \mathrm{~h}^{-1}$ in the absence of $\mathrm{Fe}^{3+}$ (batch 1) to $0.124 \mathrm{~h}^{-1}$ in the presence of $\mathrm{Fe}^{3+}$ (batch 3). The presence of $\mathrm{Fe}^{3+}$ also led to the complete consumption of glucose and biomass levels were doubled from $0.67 \mathrm{~g}$ dry cell/l to 1.10 $\mathrm{g}$ dry cell/l. The addition of $\mathrm{Mo}^{6+}$ did not increase the growth rates (batch 2) even though it did have a big effect on nitrate removal when in combination with $\mathrm{Fe}^{3+}$ (batch 4).

In the experiment described so far $800 \mathrm{mg} \mathrm{C} / \mathrm{l}$ glucose and $700 \mathrm{mg} \mathrm{NO}_{3}{ }^{-} \mathrm{-N} / \mathrm{l}$ nitrate were used as sole sources of carbon and electron acceptor, respectively. From the batch 3 it can be calculated that $800 \mathrm{mg} \mathrm{C} / \mathrm{l}$ glucose can effectively convert about $365 \mathrm{mg} \mathrm{NO}_{3}{ }^{-} \mathrm{N} / \mathrm{l}$ to $\mathrm{N}_{2}$ gas in the presence of added $\mathrm{Fe}^{3+}$. Figure 1 (batch 5) shows that 700 mg $\mathrm{NO}_{3}{ }^{-} \mathrm{N} / \mathrm{l}$ was completely reduced to $\mathrm{N}_{2}$ gas within 48 hrs when the initial glucose concentration was increased to $1,600 \mathrm{mg} \mathrm{C} / \mathrm{l}$ glucose and $\mathrm{Fe}^{3+}$ were present. In this case the levels of nitrite were always very low (0-1.5 $\left.\mathrm{mg} \mathrm{NO}_{2}^{-}-\mathrm{N} / \mathrm{l}\right)$ since more electrons were available for reduction of both nitrate and nitrite. Growth of the bacterium under complete denitrification conditions was increased to $2.08 \mathrm{~g}$ dry cell/ll. So an increase in growth of $100 \mathrm{mg}$ dry cell/l caused by addition of $\mathrm{Fe}^{3+}$ and glucose required the utilization of about $33.4 \mathrm{mg} \mathrm{NO} \mathrm{N}^{-}-\mathrm{N} / \mathrm{l}$. Addition of $\mathrm{Mo}^{6+}$ and $\mathrm{Fe}^{3+}$ had effects on growth and nitrate utilization. It was observed that within $40 \mathrm{hrs}$, nitrate exhausted. Again, a high rate of nitrate removal was achieved in the presence of both $\mathrm{Fe}^{3+}$ and $\mathrm{Mo}^{6+}$ with an initial glucose concentration of $1600 \mathrm{mg} / \mathrm{l}$ but under these conditions nitrite accumulated transiently (Figure 1) (batch 6). At $36 \mathrm{hrs}$, the levels of nitrate and accumulated nitrite in batch 6 were $35.1 \mathrm{mg} \mathrm{NO}_{3}{ }^{-} \mathrm{N} / \mathrm{l}$ and $320.2 \mathrm{mg} \mathrm{NO}{ }^{-}-\mathrm{N} / \mathrm{l}$, respectively. After nitrate exhausted, then nitrite was utilized.

The maximum biomass of batch 6 was $1.75 \mathrm{~g}$ dry cell/l. Thus growth of $100 \mathrm{mg}$ dry cell/l caused by addition of $\mathrm{Fe}^{3+}, \mathrm{Mo}^{6+}$ and glucose required the utilization of about $40.2 \mathrm{mg} \mathrm{NO}{ }_{3}^{-}-\mathrm{N} / \mathrm{l}$. In the presence of $\mathrm{Fe}^{3+}$ and $\mathrm{Mo}^{6+}$, growth of the bacterium was retarded and nitrite was accumulated. These experiments also showed that under saline conditions, Paracoccus pantotrophus P16 consumed 700 mg $\mathrm{NO}_{3}{ }^{-} \mathrm{-N} / \mathrm{l}$ (without net accumulation of nitrite) when $1,600 \mathrm{mg} \mathrm{C} / \mathrm{l}$ of glucose was added (Figure 1) (batches 5 and 6).
Time courses of growth, carbon concentration, nitrate concentration and accumulation of nitrite are shown in Figure 2. In the reactors containing $800 \mathrm{mg} \mathrm{C} / \mathrm{l}$ glucose and $1,600 \mathrm{mg} \mathrm{C} / \mathrm{l}$ glucose growth of the bacterium were 1.12 and $2.11 \mathrm{~g}$ dry cell/l, respectively and in the presence of ethanol growth was $0.72 \mathrm{~g}$ dry cell/l (Figure 2a). The results showed that both substrates were completely consumed within 36-44 hrs. However, as ethanol was consumed the bacterium produced acetate (Figure $2 \mathrm{~b}$ ). The $\mathrm{C} / \mathrm{N}$ ratio need to remove $700 \mathrm{mg} \mathrm{NO}{ }_{3}^{-}-\mathrm{N} / \mathrm{l}$ varied according to the carbon source added. When ethanol was supplied at $800 \mathrm{mg} \mathrm{C/l}$, the initial ratio of $\mathrm{C} / \mathrm{N}$ was $1.15 \mathrm{mg} \mathrm{C} / \mathrm{mg} \mathrm{NO}_{3}^{-}-\mathrm{N}$. In growth experiments with glucose the $\mathrm{C} / \mathrm{N}$ ratio was either $2.31 \mathrm{mg} \mathrm{C} / \mathrm{mg} \mathrm{NO}_{3}{ }^{-} \mathrm{N}$ or $1.15 \mathrm{mg} \mathrm{C} / \mathrm{mg} \mathrm{NO}_{3}{ }^{-} \mathrm{N}$ (Figure 2). In the presence of glucose when $\mathrm{C} / \mathrm{N}$ ratio was 1.15 only about half of the nitrate was used but it was all consumed at this initial $\mathrm{C} / \mathrm{N}$ ratio when ethanol was used (Figure 2c). Interestingly, the nature of compound used as the carbon source (glucose and ethanol) and the $\mathrm{C} / \mathrm{N}$ ratios did not cause nitrite accumulation by the bacterium. It should be noted that when ethanol was used instead of glucose in starter culture preparation step the results were same as those in Figure 2 (data not shown). Table 2 shows that if provided with ethanol, maximum dry cell weight, denitrification rate and denitrification yield were $0.72 \pm$ $0.02 \mathrm{~g} / \mathrm{l}, 9.68 \pm 0.11 \mathrm{mg} \mathrm{NO}_{3}^{-}-\mathrm{N} / \mathrm{l} / \mathrm{h}$ and $1.08 \pm 0.02 \mathrm{~g} \mathrm{NO}_{3}{ }^{-}$ -N/g C, respectively. When using glucose, denitrification rate increased to $17.56 \pm 0.18 \mathrm{mg} \mathrm{NO}_{3}{ }^{-}-\mathrm{N} / \mathrm{l} / \mathrm{h}$, while maximum dry cell weight and denitrification yield were $2.11 \pm 0.02 \mathrm{~g} / \mathrm{l}$ and $0.45 \pm 0.01 \mathrm{~g} \mathrm{NO}_{3}{ }^{-}-\mathrm{N} / \mathrm{g} \mathrm{C}$, respectively. The comparison of specific denitrification rate in term of $\mathrm{mg} \mathrm{NO}_{3}{ }^{-}-\mathrm{N} / \mathrm{h} / \mathrm{g}$ DCW revealed that ethanol was superior to those of glucose.

\section{Subcellular localization and activity of nitrate and nitrite reductases}

Testing of the 3 subcellular fractions, cytoplasmic, periplasmic and membrane fractions, for nitrate and nitrite reductase activities showed, in all cases, that nitrate reductase was present in the membrane fraction while nitrite reductase was found in the periplasmic fraction. As shown in Table 1, the membrane-bound nitrate reductase and periplasmic nitrite reductase activities were $998 \pm 28$ and $373 \pm 18 \mathrm{nmol}$ (mg protein) ${ }^{-1} \mathrm{~min}^{-1}$, respectively after growing Paracoccus pantotrophus P16 in the medium supplemented with $1.5 \mu \mathrm{M} \mathrm{Fe}^{3+}$. Of special interest was the finding that further addition of $2.4 \mu \mathrm{M} \mathrm{Mo}{ }^{6+}$ further increased the nitrate reductase activity to $6,223 \pm 502 \mathrm{nmol}$ (mg protein $)^{-1} \min ^{-1}$. However, the periplasmic nitrite reductase activity of $344 \pm 20 \mathrm{nmol}(\mathrm{mg} \text { protein) })^{-1} \mathrm{~min}^{-1}$ was slightly less than that in the absence of $2.4 \mu \mathrm{M} \mathrm{Mo}^{6+}$. It seems likely that the greater imbalance of the 2 enzymes caused by the addition of $\mathrm{Mo}^{6+}$ led to the accumulation of nitrite.

Table 1 also shows nitrate and nitrite reductase activities of whole cells. Nitrate reductase and nitrite reductase activities were $44 \pm 4$ and $18 \pm 3 \mathrm{nmol}(\mathrm{mg} \mathrm{DCW})^{-1} \mathrm{~min}^{-1}$, 
Table 2. Kinetics parameters of denitrification by Paracoccus pantotrophus P16.

\begin{tabular}{|c|c|c|}
\hline Parameter & Glucose & Ethanol \\
\hline Maximum DCW (g/l) & $2.11 \pm 0.02$ & $0.72 \pm 0.02$ \\
\hline $\begin{array}{l}\text { Denitrification rate } \\
\left(\mathrm{mg} \mathrm{NO}_{3}^{-}-\mathrm{N} / / / \mathrm{h}\right)\end{array}$ & $17.56 \pm 0.18$ & $9.68 \pm 0.11$ \\
\hline $\begin{array}{l}\text { Specific denitrification rate } \\
\left(\mathrm{mg} \mathrm{NO}_{3}^{-}-\mathrm{N} / \mathrm{h} / \mathrm{g} \mathrm{DCW}\right)\end{array}$ & $8.32 \pm 0.16$ & $13.46 \pm 0.48$ \\
\hline $\begin{array}{l}\text { Denitrification yield } \\
\quad\left(\mathrm{g} \mathrm{NO}_{3}^{-}-\mathrm{N} / \mathrm{g} \mathrm{C}\right)\end{array}$ & $0.45 \pm 0.01$ & $1.08 \pm 0.02$ \\
\hline $\mathrm{C} / \mathrm{N}\left(\mathrm{mg} \mathrm{C} / \mathrm{mg} \mathrm{NO}_{3}{ }^{-} \mathrm{N}\right)$ & $2.31 \pm 0.02$ & $1.15 \pm 0.04$ \\
\hline Time (hrs) & 40 & 72 \\
\hline
\end{tabular}

respectively when medium was supplemented with $2.4 \mu \mathrm{M}$ $\mathrm{Mo}^{6+}$ into the medium. Nitrate reductase activity was $240 \pm$ 30 while nitrite reductase activity was $162 \pm 13 \mathrm{nmol}(\mathrm{mg}$ DCW $)^{-1} \min ^{-1}$ in the culture containing $1.5 \mu \mathrm{M} \mathrm{Fe}^{3+}$. This clearly indicated the effect of $\mathrm{Fe}^{3+}$ toward the enzymes activities. On the contrary, $\mathrm{Fe}^{3+}$ and $\mathrm{Mo}^{6+}$ supported nitrate reductase activity while they slightly decreased nitrite reductase activity. The profiles of enzyme activities of whole cells and of subcellular fractions were similar. However, the results of enzyme activities in subcellular fractions were largely different with the whole cell. This due to benzyl viologen must crossed cell membranes of the bacterium prior to react with the enzymes.

\section{Nitrate and nitrite reduction by intact cells}

Enzymatic reduction of nitrate and nitrite in phosphate buffer containing $10 \mathrm{mg} \mathrm{NO}_{3}{ }^{-} \mathrm{N} / \mathrm{l}$ nitrate or $10 \mathrm{mg} \mathrm{NO}_{2}^{-}-\mathrm{N} / \mathrm{l}$ nitrite by intact cells of Paracoccus pantotrophus P16 after growth on glucose or ethanol was investigated (Figure 3). After growing cells for 24 and 32 hrs, the profiles of nitrate and nitrite reduction by intact cells were similar irrespective of the carbon substrate. Furthermore, it can be observed that under the tested conditions, the whole cells can hold the activities of nitrate and nitrite reducing enzymes over $60 \mathrm{~min}$. Also both enzymes had the activities in the presence of $3 \% \mathrm{NaCl}$.

\section{DISCUSSION}

Martienssen and Schöps (1999) observed that the accumulation of nitrite during denitrification processes has been shown to occur by (1) inhibition of nitrite reductase by nitrate due to competitive utilization between nitrate and nitrite to serve as the terminal electron acceptors, (2) inhibition of nitric oxide reductase by nitrate and the accumulated nitric oxide causing further inhibition of nitrite reductase by (3) the extreme sensitivity of nitrite reductase to inhibition by low oxygen concentrations, (4) an imbalance of nitrate and nitrite reductase activities, and (5) a delayed expression of nitrite reductase mRNA reflected in a delay to the synthesis of nitrite reductase when compared with nitrate reductase.

In this experiment, denitrification activity was influenced by the concentrations of $\mathrm{Fe}^{3+}$ and $\mathrm{Mo}^{6+}$. When $\mathrm{Fe}^{3+}$ was the only ion added, nitrate and nitrite were synergistically reduced to $\mathrm{N}_{2}$ gas. Addition of $\mathrm{Fe}^{3+}$ and $\mathrm{Mo}^{6+}$ led to nitrite accumulation although a greater rate of nitrate removal was observed (Figure 1). Enzymatic assays showed that increasing levels of $\mathrm{Fe}^{3+}$ produced increased levels of both membrane-bound nitrate and periplasmic nitrite reductase activities. $1.5 \mu \mathrm{M} \mathrm{Fe}^{3+}$ produced a 2.6 and 1.7 fold increase, respectively. However, as mentioned previously the increases in membrane-bound nitrate reductase activity were greatly increased by the further addition of $\mathrm{Fe}^{3+}$ and $\mathrm{Mo}^{6+}$. Addition of $\mathrm{Fe}^{3+}$ and $\mathrm{Mo}^{6+}$, caused the membranebound nitrate reductase activity to increase up to 16-21 fold while the increase in periplasmic nitrite reductase activity was only about 1.5-3 fold (Table 1). Therefore an overstimulation of membrane bound nitrate reductase activity as compared to periplasmic nitrite reductase activity caused an accumulation of nitrite.

It is already known that the membrane-bound nitrate reductase (Nar) enzyme required by bacterial denitrifiers contains a Mo-molybdopterin complex (González et al. 2006). Tavares et al. (2006) also reported that Fe and Mo are required for membrane-bound nitrate reductase enzymes. An increase in the concentration of $\mathrm{Fe}^{2+}$ or $\mathrm{Mo}^{6+}$ to $70 \mathrm{mg} / \mathrm{dm}^{3}$ or $5 \mathrm{mg} / \mathrm{dm}^{3}$, respectively resulted in an increase in the nitrate removal (Cyplik et al. 2007). The periplasmic nitrite reductases of Paracoccus spp. are cytochrome $c d_{1}$ type, which contained hemes as a major component (Moura and Moura, 2001; Einsle and Kroneck, 2004). Although, trace elements, i.e. $\mathrm{Cu}, \mathrm{Zn}$ and $\mathrm{Mn}$ were 
found in yeast extract; comparison the results of batch 1 with the others were clearly indicated the effect of adding metal ions (Figure 1).

Figure 1 (batches 5 and 6) shows that adding glucose to 4 $\mathrm{g} / \mathrm{l}$ led to complete nitrate reduction. Even the $\mathrm{C} / \mathrm{N}$ ratio was $2.31 \mathrm{mg} \mathrm{C} / \mathrm{mg} \mathrm{NO}_{3}{ }^{-} \mathrm{N}$; transient accumulation of high nitrite concentration was observed when $\mathrm{Fe}^{3+}$ and $\mathrm{Mo}^{6+}$ were present. In addition, the accumulated nitrite in the presence of $\mathrm{Fe}^{3+}$ and $\mathrm{Mo}^{6+}$ still remained when culture medium was limited (Figure 1) (batch 4). This accumulated nitrite could be highly toxic to human and aquatic animals when it was contaminated to environments (Chow and Hong, 2002; Jensen, 2003). Importantly, many researches reported that the presence of nitrite accumulated during the denitrification process can promote an accumulation of nitric and nitrous oxides, reflecting incomplete denitrification processes (Schulthess et al. 1995; Béline et al. 1999; Alinsafi et al. 2008). The emission of nitrous oxide $\left(\mathrm{N}_{2} \mathrm{O}\right)$ also causes undesirable environmental problems, such as the green house effect and ozone depletion in the stratosphere (Park et al. 2000).

Therefore, metal ion concentration is the critical parameter that affects the ability of denitrifying bacteria to remove nitrate and nitrite. It is emphasized that the amount of $\mathrm{Fe}^{3+}$ and $\mathrm{Mo}^{6+}$ to be added in the treatment system should be carefully controlled. In order to control denitrification rate, without an accumulation of nitrite, a suitable concentration of trace metals should be supplied. Under experiments to be tested, the membrane-bound nitrate reductase had 2.7 fold higher activity than periplasmic nitrite reductase activity was the optimized conditions to control denitrification rate.

The results showed that nitrate reductase was found in the membrane fraction and was therefore regarded as a true respiratory enzyme to drive ATP synthesis for anaerobic nitrate respiration. In contrast the periplasmic nitrate reductase can be referred to as a dissimilatory enzyme because it can be expressed under both aerobic and anaerobic conditions but it cannot generate proton motive force during electron transfer in the quinol-Nap span (Steenhoudt et al. 2001; Gates et al. 2003). Western blot analysis was performed and showed that the intensity of the $\sim 140 \mathrm{kDa}$ band of NarG, a catalytic subunit of membranebound nitrate reductase, was similar under conditions containing only $\mathrm{Fe}^{3+}$ or $\mathrm{Fe}^{3+}$ and $\mathrm{Mo}^{6+}$ (data not shown). The results imply that added $\mathrm{Fe}^{3+}$ and $\mathrm{Mo}^{6+}$ may not have a direct effect on the expression of membrane-bound nitrate reductase, but they may have a direct influence on enzyme activity.

Several types of carbon source have been reported for supporting heterotrophic denitrification, but capability to use these substrates can be different in different microorganisms (Kesserü et al. 2002; KariminiaaeHamedaani et al. 2004; Cyplik et al. 2007). In this study, the application of glucose and ethanol in the process enabled complete removal of $700 \mathrm{mg} \mathrm{NO}_{3}{ }^{-}-\mathrm{N} / \mathrm{l}$ without accumulation of nitrite. The $\mathrm{C} / \mathrm{N}$ ratio for complete denitrification when glucose was supplied was $2.31 \mathrm{mg}$ $\mathrm{C} / \mathrm{mg} \mathrm{NO}_{3}{ }^{-}-\mathrm{N}$. Whereas for ethanol it was $1.15 \mathrm{mg} \mathrm{C} / \mathrm{mg}$ $\mathrm{NO}_{3}{ }^{-} \mathrm{N}$ with an efficient denitrification yield of $1.08 \pm 0.02$ $\mathrm{g} \mathrm{NO}_{3}^{-}-\mathrm{N} / \mathrm{g}$ C. Also, as reported by Her and Huang (1995) and Gómez et al. (2000), the optimal C/N ratio suggested for complete of denitrification was 1.08 and 2.00 for ethanol and glucose, respectively. On addition of glucose, the biomass increased as also observed by Cyplik et al. (2007). Although glucose was reported to be a poor substrate for denitrification (Etchebehere et al. 2001, Cyplik et al. 2007), but a greater denitrification rate of $17.56 \pm 0.18 \mathrm{mg} \mathrm{NO}{ }_{3}^{-} \mathrm{-N} / \mathrm{l} / \mathrm{h}$ was obtained by Paracoccus pantotrophus $\mathrm{P} 16$ grown in the presence of glucose. The experiment with ethanol showed a greater effect in term of specific denitrification rate $\left(13.46 \pm 0.48 \mathrm{mg} \mathrm{NO}_{3}{ }^{-} \mathrm{-N} / \mathrm{h} / \mathrm{g}\right.$ DCW). Therefore, an application of glucose and ethanol containing waste as sole of carbon source for denitrification in nitrate/nitrite-containing wastes by Paracoccus pantotrophus $\mathrm{P} 16$ is an alternative for a cost effective process.

The whole cells to be collected from cultures broth could reduce nitrate and nitrite. The activities of nitrate and nitrite reduction can sustain over $60 \mathrm{~min}$; therefore it is possible to apply the cells for decreasing nitrate and nitrite contents in water, foodstuffs, vegetable and fruit juices (WalkowiakTomczak, 2002; Okafor and Ogbonna, 2003).

\section{CONCLUDING REMARKS}

This work has reported the effects of metal ions, $\mathrm{Fe}^{3+}$ and $\mathrm{Mo}^{6+}$, carbon sources, $\mathrm{C} / \mathrm{N}$ ratios on the growth, the rate of nitrate removal, nitrite accumulation and nitrate and nitrite reductase activities of a halotolerant Paracoccus pantotrophus P16 growing under saline environments and under denitrifying conditions. The presence of both $\mathrm{Fe}^{3+}$ and $\mathrm{Mo}^{6+}$ caused an accumulation of nitrite; this was consistent with the observed nitrate and nitrite reductase activities. The bacterium had an ability to remove $700 \mathrm{mg}$ $\mathrm{NO}_{3}{ }^{-}-\mathrm{N} / \mathrm{l}$ within $40 \mathrm{hrs}$ when $1,600 \mathrm{mg} \mathrm{C} / \mathrm{l}$ glucose and 4.5 $\mu \mathrm{M} \mathrm{Fe}^{3+}$ were added. If given $800 \mathrm{mg} \mathrm{C} / \mathrm{l}$ ethanol, $700 \mathrm{mg}$ $\mathrm{NO}_{3}{ }^{-}-\mathrm{N} / \mathrm{l}$ was removed within $72 \mathrm{hrs}$.

\section{REFERENCES}

ALINSAFI, Asma; ADOUANI, Nouceiba; BÉLINE, Fabrice; LENDORMI, Thomas; LIMOUSY, Lionel and SIRE, Oliver. Nitrite effect on nitrous oxide emission from denitrifying activated sludge. Process Biochemistry, June 2008, vol. 43, no. 6, p. 683-689.

ASADUZZAMAN, M.; WAHAB, M.A.; VERDEGEM, M.C.J.; HUQUE, S.; SALAM, M.A. and AZIM, M.E. C/N ratio control and substrate addition for periphyton development jointly enhance freshwater prawn Macrobrachium rosenbergii production in ponds. Aquaculture, August 2008, vol. 280, no. 1-4, p. 117-123. 
AVNIMELECH, Yoram. Carbon/nitrogen ratio as a control element in aquaculture systems. Aquaculture, June 1999, vol. 176, no. 3-4, p. 227-235.

BÉLINE, F.; MARTINEZ, J.; CHADWICK, D.; GUIZIOU, F. and COSTE, C.-M. Factors affecting nitrogen transformations and related nitrous oxide emissions from aerobically treated piggery slurry. Journal of Agricultural Engineering Research, July 1999, vol. 73, no. 3, p. 235243.

BELL, Louise C.; RICHARDSON, David J. and FERGUSON, Stuart J. Periplasmic and membrane-bound respiratory nitrate reductases in Thiosphaera pantotropha: The periplasmic enzyme catalyzes the first step in aerobic denitrification. FEBS Letters, June 1990, vol. 265, no. 1-2, p. 85-87.

BILANOVIC, D.; BATTISTONI, P.; CECCHI, F.; PAVAN, P. and MATA-ALVAREZ, J. Denitrification under high nitrate concentration and alternating anoxic conditions. Water Research, October 1999, vol. 33, no. 15, p. 3311-3320.

CARRERA, J.; VICENT, T. and LAFUENTE, F.J. Influence of temperature on denitrification of an industrial high-strength nitrogen wastewater in a two-sludge system. Water SA, January 2003, vol. 29, no. 1, p. 11-16.

CERVANTES, Francisco; MONROY, Oscar and GOMEZ, Jorge. Accumulation of intermediates in a denitrifying process at different copper and high nitrate concentrations. Biotechnology Letters, October 1998, vol. 20, no. 10, p. 959-961.

CHENG, Sha-Yen and CHEN, Jiann-Chu. The time-course change of nitrogenous excretion in the Kuruma shrimp Penaeus japonicus following nitrite exposure. Aquatic Toxicology, February 2001, vol. 51, no. 4, p. 443-454.

CHOW, C.K. and HONG, C.B. Dietary vitamin E and selenium and toxicity of nitrite and nitrate. Toxicology, November 2002, vol. 180, no. 2, p. 195-207.

CRAB, Roselien; AVNIMELECH, Yoram; DEFOIRDT, Tom; BOSSIER, Peter and VERSTRAETE, Willy. Nitrogen removal techniques in aquaculture for a sustainable production. Aquaculture, September 2007, vol. 270, no. 1-4, p. 1-14.

CYPLIK, Pawel; GRAJEK, Wlodzimierz; MARECIK, Roman and KROLICZAK, Pawel. Effect of macro/micro nutrients and carbon source over the denitrification rate of Haloferax denitrifications archaeon. Enzyme and Microbial Technology, January 2007, vol. 40, no. 2, p. 212-220.

EINSLE, O. and KRONECK, P.M.H. Structural basis of denitrification. Biological Chemistry, October, 2004, vol. 385, no. 10, p. 875-883.
ESTUARDO, Carolina; MARTI, M. Cristina; HUILIÑIR, César; ÁSPE LILLO, Estrella and ROECKEL VON BENNEWITZ, Marlene. Improvement of nitrate and nitrite reduction rates prediction. Electronic Journal of Biotechnology, July 2008, vol. 11, no. 3, p. 1-10.

ETCHEBEHERE, Claudia; ERRAZQUIN, Inés; BARRANDEGUY, Elena; DABERT, Patrick; MOLETTA, René and MUXI, Lucía. Evaluation of the denitrifying microbiota of anoxic reactors. FEMS Microbiology Ecology, May 2001, vol. 35, no. 3, p. 259-265.

FERGUSON, Stuart J. Nitrogen cycle enzymology. Current Opinion in Chemical Biology, April 1998, vol. 2, no. 2, p. 182-193.

FOGLAR, Lucija; BRIŠKI, Felicita; SIPOS, Laszlo and VUKOVIĆ, Marija. High nitrate removal from synthetic wastewater with the mixed bacterial culture. Bioresource Technology, May 2005, vol. 96, no. 8, p. 879-888.

GATES, Andrew J.; HUGHES, Richard O.; SHARP, Sara R.; MILliNGTON, Paul D.; NILAVONGSE, Arjaree; COLE, Jeffrey A.; LEACH, Emily-Rose.; JEPSON, Brian; RICHARDSON, David J. and BUTLER, Clive S. Properties of the periplasmic nitrate reductases from Paracoccus pantotrophus and Escherichia coli after growth in tungsten-supplemented media. FEMS Microbiology Letters, March 2003, vol. 220, no. 2, p. 261-269.

GLASS, Charles and SILVERSTEIN, Joann. Denitrification kinetics of high nitrate concentration water: $\mathrm{pH}$ effect on inhibition and nitrite accumulation. Water Research, March 1998, vol. 32, no. 3, p. 831-839.

GLASS, Charles and SILVERSTEIN, Joann. Denitrification of high-nitrate, high-salinity wastewater. Water Research, January 1999, vol. 33, no. 1, p. 223-229.

GÓMEZ, M.A.; GONZÁLEZ-LÓPEZ, J. and HONTORIA-GARCÍA, E. Influence of carbon source on nitrate removal of contaminated groundwater in a denitrifying submerged filter. Journal of Hazardous Materials, December 2000, vol. 80, no. 1-3, p. 69-80.

GONZÁLEZ, P.J.; CORREIA， C.; MOURA， I.; BRONDINO, C.D. and MOURA, J.J.G. Bacterial nitrate reductases: molecular and biological aspects of nitrate reduction. Journal of Inorganic Biochemistry, May 2006, vol. 100, no. 5-6, p. 1015-1023.

HARI, B.; MADHUSOODANA, K.; VARHHESE, J.T.; SCHRAMA, J.W. and VERDEGEM, M.C.J. Effects of carbohydrate addition on production in extensive shrimp culture systems. Aquaculture, November 2004, vol. 241, no. 1-4, p. 179-194.

HER, Jiunn-Jye and HUANG, Ju-Sheng. Influence of carbon source and $\mathrm{C} / \mathrm{N}$ ratio on nitrate/nitrite denitrification 
and carbon breakthrough. Bioresource Technology, 1995, vol. 54, no. 1, p. 45-51.

JENSEN, Frank B. Nitrite disrupts multiple physiological functions in aquatic animals. Comparative Biochemistry and Physiology, May 2003, vol. 135, no. 1, p. 9-24.

KARIMINIAAE-HAMEDAANI, Hamid-Reza; KANDA, Kohzo and KATO, Fumio. Denitrification activity of the bacterium Pseudomonas sp. ASM-2-3 isolated from the Ariake sea tideland. Journal of Bioscience and Bioengineering, 2004, vol. 97, no. 1, p. 39-44.

KESSERÜ, Péter; KISS, István; BIHARI, Zoltán and POLYÁK, Béla. Investigation of the denitrification activity of immobilized Pseudomonas butanovora cells in the presence of different organic substrates. Water Research, March 2002, vol. 36, no. 6, p. 1565-1571.

KIR, M.; KUMLU, M. and EROLDOĞAN, O.T. Effects of temperature on acute toxicity of ammonia to Penaeus semisulcatus juveniles. Aquaculture, November 2004, vol. 241, no. 1-4, p. 479-489.

LABBÉ, Normand; PARENT, Serge and VILLEMUR, Richard. Addition of trace metals increases denitrification rate in closed marine systems. Water Research, February 2003, vol. 37, no. 4, p. 914-920.

LORRAIN, M-J.; TARTAKOVSKY, B.; PEISAJOVICHGILKSTEIN, A. and GUIOT, S.R. Comparison of different carbon sources for ground water denitrification. Environmental Technology, September 2004, vol. 25, no. 9, p. 1041-1049.

MARTIENSSEN, M. and SCHÖPS, R. Population dynamics of denitrifying bacteria in a model biocommunity. Water Research, February 1999, vol. 33, no. 3, p. 639-646.

MISHRA, Jeet K.; SAMOCHA, Tzachi M.; PATNAIK, Susmita; SPEED, Mike; GANDY, Ryan L. and ALI, Abdul-Mehdi. Performance of an intensive nursery system for the pacific white shrimp Litopenaeus vannamei under limited discharge condition. Aquacultural Engineering, January 2008, vol. 38, no. 1, p. 2-15.

MOURA, Isabel and MOURA, José J.G. Structural aspects of denitrifying enzymes. Current Opinion in Chemical Biology, April 2001, vol. 5, no. 2, p. 168-175.

OKAFOR, P.N. and OGBONNA, U.I. Nitrate and nitrite contamination of water sources and fruit juices marketed in South-Eastern Nigeria. Journal of Food Composition and Analysis, April 2003, vol. 16, no. 2, p. 213-218.

OKEKE, Benedict C.; GIBLIN, Tara and FRANKENBERGER Jr., William $\mathrm{T}$. Reduction of perchlorate and nitrate by salt tolerant bacteria.
Environmental Pollution, August 2002, vol. 118, no. 3, p. 357-363.

PARK, Ki Young; INAMORI, Yuhei; MIZUOCHI, Motoyuki and AHN, Kyu Hong. Emission and control of nitrous oxide from a biological wastewater treatment system with intermittent aeration. Journal of Bioscience and Bioengineering, 2000, vol. 90, no. 3, p. 247-252.

PHILIPPOT, L. and HØJBERG, O. Dissimilatory nitrate reductase in bacteria. Biochimica et Biophysica Acta - Gene Structure and Expression, July 1999, vol. 1449, no. 1-2, p. 1-23.

REZIĆ, Tončy; ŠANTEK, Božidar; NOVAK, Srđan and MARIĆ, Vladimir. Comparison between the heterotrophic cultivation of Paracoccus denitrificans in continuous stirred tank reactor and horizontal rotating tubular bioreactor. Process Biochemistry, September 2006, vol. 41, no. 9, p. 2024-2028.

SASAKI, K.; MORII, H.; NISHIZAWA, Y. and NAGAI, S. Denitrifying and photoheterotrophic growth of Rhodobacter sphaeroides S under anaerobic-dark and -light conditions. Journal of Fermentation Technology, 1988, vol. 66 , no. 1, p. 27-32.

SCHULTHESS, R.V.; KÜHNI, M. and GUJER, W. Release of nitric and nitrous oxides from denitrifying activated sludge. Water Research, January 1995, vol. 29, no. 1, p. 215-226.

SHIAU, Shi-Yen. Nutrient requirements of penaeid shrimps. Aquaculture, May 1998, vol. 164, no. 1-4, p. 7793.

STEENHOUDT, Oda; KEIJERS, Veerle; OKON, Yaacov and VANDERLEYDEN, Jos. Identification and characterization of a periplasmic nitrate reductase in Azospirillum brasilence Sp245. Archives of Microbiology, May 2001, vol. 175, no. 5, p. 344-352.

TAVARES, P.; PEREIRA, A.S.; MOURA, J.J.G. and MOURA, I. Metalloenzymes of the denitrification pathway. Journal of Inorganic Biochemistry, December 2006, vol. 100, no. 12, p. 2087-2100.

VAN RIJN, Jaap; TAL, Yossi and SCHREIER, Harold J. Denitrification in recirculating systems: theory and applications. Aquacultural Engineering, May 2006, vol. 34, no. 3, p. 364-376.

WALKOWIAK-TOMCZAK, Dorota. Microbiological denitrification of red beet juice. European Food Research and Technology, November 2002, vol. 215, no. 5, p. 401406.

YILDIZ, Hijran Yavuzcan and BENLI, A. Caglan Karasu. Nitrite toxicity to crayfish, Astacus leptodactylus, the effects of sublethal nitrite exposure on hemolymph nitrite, 
total hemocyte counts, and hemolymph glucose. Ecotoxicology and Environmental Safety, November 2004, vol. 59, no. 3, p. 370-375.

ZHOU, Qi; TAKENAKA, Shinji; MURAKAMI, Shuichiro; SEESURIYACHAN, Phisit; KUNTIMA, Ampin and AOKI, Kenji. Screening and characterization of bacteria that can utilize ammonium and nitrate ions simultaneously under controlled cultural conditions. Journal of Bioscience and Bioengineering, February 2007, vol. 103, no. 2, p. 185-191. 